\title{
Thermal, Structural and Morphological Characterisation of Freeze-dried Copper(II) Acetate Monohydrate and its Solid Decomposition Products
}

\author{
J.V. Bellini ${ }^{\mathrm{a}}$, R. Machado $^{\mathrm{b}}$, M.R. Morelli ${ }^{\mathrm{b}}$, R.H.G.A. Kiminami ${ }^{\mathrm{b}}$ \\ ${ }^{a}$ Departamento de Física (DFI), Universidade Estadual de Maringá (UEM) \\ Av. Colombo 5790, Zona 07, 87020-900 Maringá - PR, Brasil \\ ${ }^{b}$ Departamento de Engenharia de Materiais (DEMa), Universidade Federal \\ de São Carlos (UFSCar), Rodovia Washington Luis, km 235 \\ C.P. 676, 13565-905 São Carlos - SP, Brasil
}

Received: December 3, 2001; Revised: June 25, 2002

\begin{abstract}
In the present study the thermal decomposition of a freeze-dried copper(II) acetate monohydrate powder, $\left(\mathrm{CH}_{3} \mathrm{COO}\right)_{2} \mathrm{Cu}_{2} \mathrm{O},\left(\mathrm{FDCuAcH} \mathrm{H}_{2} \mathrm{O}\right)$, was analysed by a combination of high-temperature $\mathrm{X}$-ray diffractometry; differential scanning calorimetry and thermogravimetry, up to $700{ }^{\circ} \mathrm{C}$. The structure and morphology of the calcined freeze-dried powders were analysed by scanning electron microscopy and X-ray diffractometry. The results showed that $\mathrm{FDAcCuH}_{2} \mathrm{O}$ decomposes during heating in two stages: I) $\left(25-225{ }^{\circ} \mathrm{C}\right) \mathrm{FDCuAcH}_{2} \mathrm{O}$ dehydrates giving rise to copper(II) acetate, $\left(\mathrm{CH}_{3} \mathrm{COO}\right)_{2} \mathrm{Cu},(\mathrm{AcCu})$, and II) $\left(225-525^{\circ} \mathrm{C}\right) \mathrm{AcCu}$ decomposes to $\mathrm{CuO}$ through complex oxidation reactions of $\mathrm{Cu}$ and $\mathrm{Cu}_{2} \mathrm{O}$, simultaneously. SEM showed that $\mathrm{FDCuAcH}_{2} \mathrm{O}$ powder has a scale-like morphology, which is created in the freezing stage and retained after freeze-drying. After calcination at 125 and $225^{\circ} \mathrm{C}$, clusters of elongated tubes (or filaments) compose the resulting powder ( $\mathrm{AcCu}$ ). Subsequent calcination at temperatures above $325{ }^{\circ} \mathrm{C}$ resulted in hard clusters of spheroid-like $\mathrm{CuO}$ particles.
\end{abstract}

Keywords: freeze-drying, copper(II) acetate monohydrate, thermal decomposition, $\mathrm{Cu}$ oxides, high-temperature $X$-ray diffractometry

\section{Introduction}

In general, powders of hydrate metal acetates have the form $\left(\mathrm{CH}_{3} \mathrm{COO}\right)_{2} M \cdot x \mathrm{H}_{2} \mathrm{O}$, where $M$ is a metal cation, $\mathrm{CH}_{3} \mathrm{COO}$ is an acetate group and $x$ is the number of water molecules. These materials are useful reagents commercially available and are used mainly in industrial processes. Although metal acetates are technologically important materials only recently systematic data about their solubilities in water as a function of temperature have been published ${ }^{1}$.

The fact that metal acetates (including nitrates, oxalates, sulphates, etc.) are water-soluble salts indicates that they can be freeze-dried individually or in multi-components. In the conventional freeze-drying ${ }^{2}$ (or cryochemical) process, the starting salts of high purity are initially dissolved in an adequate solvent, rapidly frozen to avoid precipitation or segregation of the components, followed by solvent sublimation under vacuum. The resulting powders obtained in this way are expected to be chemically more homogeneous, free of contamination by impurities and highly reactive. After thermal decomposition and solid state reactions in high temperature the precursors give rise to a more uniform mixture of metal oxides in atomic scale. Freeze-drying have been used to make improvements in the powder synthesis of catalysts ${ }^{3}$, PLZT ${ }^{4,5}$, ferrites ${ }^{6}$ and superconductors $^{6-9}$. Recently, scientific and technological efforts have been carried out through the utilisation of the freeze-drying technique to produce homogenous mixtures of powders such as oxides with copper(II) acetate monohydrate $\left(\mathrm{CH}_{3} \mathrm{COO}\right)_{2} \mathrm{Cu} \cdot \mathrm{H}_{2} \mathrm{O}$ (denoted $\mathrm{CuAcH}_{2} \mathrm{O}$ in the text for simplification) which have been used as precursors to preparation of $\mathrm{ZnO}$-based varistors ${ }^{10,11}$.

*e-mail: morelli@power.ufscar.br 
In the last decades much work has been published in the literature ${ }^{9,10,12-18}$ on thermal decomposition of $\mathrm{CuAcH}_{2} \mathrm{O}$, under various conditions, to understand the thermal events involved in the solid-gas-solid reactions and the products of such reactions. This material has been investigated by differential thermal analysis (DTA) $)^{9,12,14,15,18}$, thermogravimetry $(\mathrm{TG})^{13-16,18}$, differential scanning calorimetry $(\mathrm{DSC})^{18}, \mathrm{X}$-ray diffractrometry (XRD) $)^{9,12,16,18,19-21}$, scanning electron microscopy (SEM) $)^{9,17,18}$, both infrared (IR) and Raman spectroscopy ${ }^{9,13,14,18,22}$. These previously mentioned works pointed out that thermal decomposition course of $\mathrm{CuAcH}_{2} \mathrm{O}$ occurs in two stages: I) dehydration of $\mathrm{CuAcH}_{2} \mathrm{O}$ producing copper(II) acetate $\left(\left(\mathrm{CH}_{3} \mathrm{COO}\right)_{2} \mathrm{Cu}\right)$ (denoted by $\mathrm{CuAc}$ ) and II) decomposition of $\mathrm{CuAc}$ producing solid products such as $\mathrm{Cu}, \mathrm{Cu}_{2} \mathrm{O}, \mathrm{CuO}$ or more rarely to $\mathrm{Cu}_{4} \mathrm{O}_{3}$, and gaseous or volatile products such as acetic acid, acetone, acetaldehyde, methane, carbon dioxide, and hydrogen. The range of temperatures of such thermal events and the resulting solid products may depend on the atmosphere, heating rate and origin of the powder.

In this work, the thermal decomposition course of a freeze-dried $\left(\mathrm{CH}_{3} \mathrm{COO}\right)_{2} \mathrm{Cu} \cdot \mathrm{H}_{2} \mathrm{O}$ powder (denoted $\mathrm{FDCuAcH}_{2} \mathrm{O}$ ) have been studied by DSC and TG, in static air, up to $700{ }^{\circ} \mathrm{C}$. The structural and morphological changes have been characterised by RXD and SEM, at ambient temperature, after calcination in air, in various temperatures up to $625^{\circ} \mathrm{C}$. For the first time on literature the results of in situ characterisation by high-temperature $\mathrm{X}$-ray diffractometry (HTXRD) up to $600{ }^{\circ} \mathrm{C}$ of a $\mathrm{FDCuAcH}_{2} \mathrm{O}$ powder are showed. The main aim of this study was to obtain more information about thermally-induced structural modifications to decide for a better condition of thermal treatment to get a desired phase.

\section{Experimental}

From literature ${ }^{1}$, a solubility limit value of $0.38 \mathrm{~mol} . \mathrm{kg}^{-1}$, for $\mathrm{AcCuH}_{2} \mathrm{O}$, in water, at $25^{\circ} \mathrm{C}$, corresponds to about $19 \mathrm{~g}$ of $\mathrm{AcCuH}_{2} \mathrm{O}$ for $250 \mathrm{ml}$ of water. Thus, a certain mass of $\mathrm{AcCuH}_{2} \mathrm{O}$ was chosen in this wok to be below of its solubility limit. Initially, $15 \mathrm{~g}$ of copper(II) acetate monohydrate $\left(\mathrm{CH}_{3} \mathrm{COO}\right)_{2} \mathrm{Cu} \cdot \mathrm{H}_{2} \mathrm{O}$ powder (Mallinckrodt, $98.7 \%$ ) was homogeneously diluted in $250 \mathrm{ml}$ of distilled-deionized water, at ambient temperature. The $\mathrm{pH}$ value of the resulting aqueous mixture was around 6.7 indicating that there was no excess of acid products formed. In this work, the freeze-drying process consisted of two stages: $i)$ freezing: the aqueous mixture was transferred to an appropriate glass flask and connected to a continuous freezing system (Edwards Shell Freezer). In this system, the flask (semidipped) rotated slowly and continuously ( $45 \mathrm{~min})$ in contact to a refrigerant fluid $\left(-50{ }^{\circ} \mathrm{C}\right)$, at atmospheric pressure, until the aqueous mixture was completely frozen. After this step, overlapped thin frozen layers were created inside the flask; ii) drying: the flask was transferred and connected into the freeze-drier. A vacuum pump (Edwards E2M2) and a water trap (Edwards Micromodulyo) compose this equipment. During this stage the water sublimates and it was captured in the trap $\left(-45^{\circ} \mathrm{C}\right)$. After about 16 hours the powder was completely dry. During freeze-drying, the pressure inside the vacuum system (trap) was maintained at $2.4 \times 10^{-2}$ torr. The $\mathrm{pH}$ of the trapped water, at ambient temperature, after freeze-drying was around 6.2.

The thermal decomposition course of the resulting FDCuAcH $\mathrm{O}_{2} \mathrm{O}$ powder was examined on heating up to $600{ }^{\circ} \mathrm{C}$, at heating rate of $5{ }^{\circ} \mathrm{C} / \mathrm{min}$, in static air, by DSC and TG (Netzsch). The solid products from the thermal decomposition of $\mathrm{FDCuAcH}_{2} \mathrm{O}$ were identified in-situ using HTXRD (Siemens D5000). The powder was Joule-heated inside a Pt-crucible, at heating rate of $5^{\circ} \mathrm{C} / \mathrm{min}$. The X-ray diffraction measurements were performed in a fixed range $34<2 \theta<40^{\circ}$, at ambient temperature, and in intervals of $100{ }^{\circ} \mathrm{C}$ during heating up to $600{ }^{\circ} \mathrm{C}$; at $300{ }^{\circ} \mathrm{C}$ and at ambient temperature, during cooling.

The $\mathrm{FDCuAcH}_{2} \mathrm{O}$ powders were calcined at various temperatures up to $625^{\circ} \mathrm{C}$, in intervals of $125^{\circ} \mathrm{C}$. The powders were calcined during $1 \mathrm{~h}$; in static air atmosphere, using a $\mathrm{Al}_{2} \mathrm{O}_{3}$-crucibles, in a electric furnace (EDG3000). During the calcinations, a constant heating and cooling rate of $5{ }^{\circ} \mathrm{C} / \mathrm{min}$ was used. XRD measurements (Siemens D5000) were performed, at ambient temperature, for the FDCuAcH $\mathrm{H}_{2} \mathrm{O}$ and calcined powders, in the range $5<2 \theta<80^{\circ}$. The morphological aspects of the powders were analysed by SEM (Leica StereoScan 440) using secondary electrons, after Au-recovering.

\section{Results and Discussion}

The curves of thermal analysis of the $\mathrm{FDCuAcH}_{2} \mathrm{O}$ powder by DSC and TG are presented in the Fig. 1. DSC and TG measurements indicate that $\mathrm{FDAcCuH}_{2} \mathrm{O}$ decomposes via two processes of weight loss (thermal events I and II) over the temperature range $100-325^{\circ} \mathrm{C}$ :

Event I: $\left(100-190^{\circ} \mathrm{C}\right)$ corresponds to dehydration, with an endothermic maximum peak at $145{ }^{\circ} \mathrm{C}$, corresponding to a weight loss about $11.9 \%$ at $190{ }^{\circ} \mathrm{C}$. Normally, in both DTA and DSC, the obtained maximum or minimum temperature values are dependent on heating rate, shifting to right as heating rate is increasing ${ }^{18}$. Evidences from literature $^{9,12,14-16,18}$ show that the first stage is mainly related to dehydration of $\left(\mathrm{CH}_{3} \mathrm{COO}\right)_{2} \mathrm{Cu}_{2} \mathrm{O}\left(\mathrm{CuAcH}_{2} \mathrm{O}\right)$ leading to formation of copper(II) acetate $\left(\mathrm{CH}_{3} \mathrm{COO}\right)_{2} \mathrm{Cu}(\mathrm{CuAc})$. The theoretical mass loss of water molecules of $\mathrm{CuAcH}_{2} \mathrm{O}$ corresponds to $9.0 \%$. In this study, the greater weight loss than that expected for the formation of $\mathrm{CuAc}$ could be also attributed to the volatilisation of $\mathrm{CuAc}$ or water excess, in the 


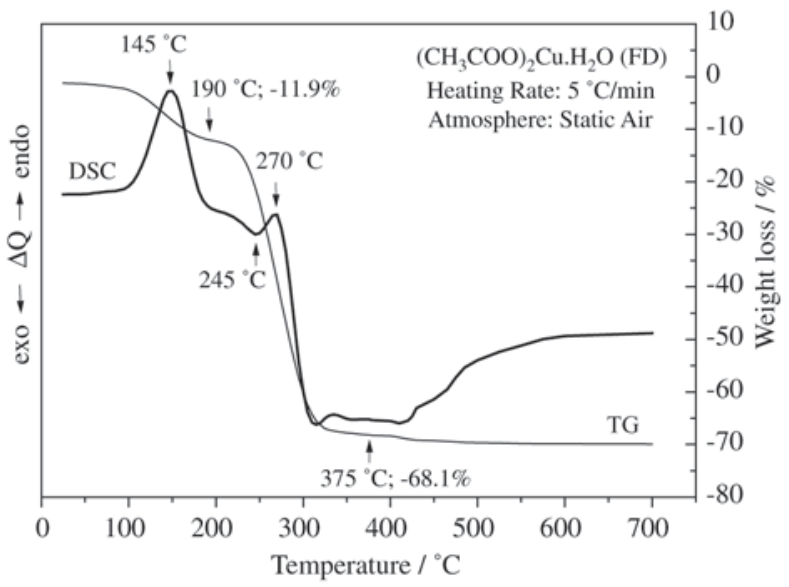

Figure 1. Curves of DSC and TG for a freeze-dried copper(II) acetate monohydrate powder.

FDCuAcH $H_{2} \mathrm{O}$ powder. The gas atmosphere significantly affects the mechanism of dehydration of $\mathrm{CuAcH}_{2} \mathrm{O}$. Under vacuum, dynamic $\mathrm{Ar}$ or $\mathrm{N}_{2}$, CuAc sublimates and copper is $\operatorname{lost}^{9,13,15,18}$.

Event II: $\left(220-325{ }^{\circ} \mathrm{C}\right)$ corresponds to decomposition of CuAc. In this range, DSC showed two double peaks: an exothermic at $245^{\circ} \mathrm{C}$, followed by an endothermic at $270{ }^{\circ} \mathrm{C}$. These peaks are related to complex solid-gas-solid reactions involving probably the production of solid metallic copper $\left(\mathrm{Cu}^{0}\right)$ and volatile or gaseous products. TG showed that the mass loss at $375{ }^{\circ} \mathrm{C}$ was about $68.1 \%$, which is equivalent to the theoretical mass loss to formation of $\mathrm{Cu}^{0}$ $(68.17 \%)$. The decomposition of $\mathrm{CuAcH}_{2} \mathrm{O}$ is greatly affected by the ambient atmosphere. In general, researchers ${ }^{9-18}$ have been relating that in vacuum, $\mathrm{N}_{2}$ or $\mathrm{Ar}$, and in air, the main solid products have been $\mathrm{Cu}^{0}$ and $\mathrm{Cu}_{2} \mathrm{O}, \mathrm{CuO}$ or $\mathrm{Cu}_{4} \mathrm{O}_{3}$, respectively. The gaseous or volatile products have been mainly composed by acetone $\left(\mathrm{CH}_{3} \mathrm{CH}_{3} \mathrm{CO}\right)$, acetic acid $\left(\mathrm{CH}_{3} \mathrm{COOH}\right)$, acetaldehyde $\left(\mathrm{CH}_{3} \mathrm{CHO}\right)$, methane $\left(\mathrm{CH}_{4}\right)$, carbon dioxide $\left(\mathrm{CO}_{2}\right)$, and hydrogen gas $\left(\mathrm{H}_{2}\right)$.

The results of HTXRD for the range $34^{\circ}<2 \theta<40^{\circ}$ performed in air, at atmospheric pressure, are showed in Fig. 2. This range of study was especially chosen because it includes the diffraction planes of relative maximum intensity for the crystalline phases $\mathrm{CuO}$ and $\mathrm{Cu}_{2} \mathrm{O}$, i.e., (-111) at $2 \theta=35,55^{\circ}$ and (111) at $2 \theta=36,41^{\circ}$, respectively. Three phases were monitored and identified by card number from powder diffraction files (PDF) of the joint committee on powder diffraction standards (JCPDS): $\mathrm{CuO}$ (tenorite) or copper(II) oxide (PDF 5-0661); $\mathrm{Cu}_{2} \mathrm{O}$ (cuprite) or copper(I) oxide (PDF 5-0667); ( $\left.\mathrm{CH}_{3} \mathrm{COO}\right)_{2} \mathrm{Cu} . \mathrm{H}_{2} \mathrm{O}$ (copper(II) acetate monohydrate) or copper acetate hydrate (PDF 27-0145). At ambient temperature $\left(25^{\circ} \mathrm{C}\right)$, XRD

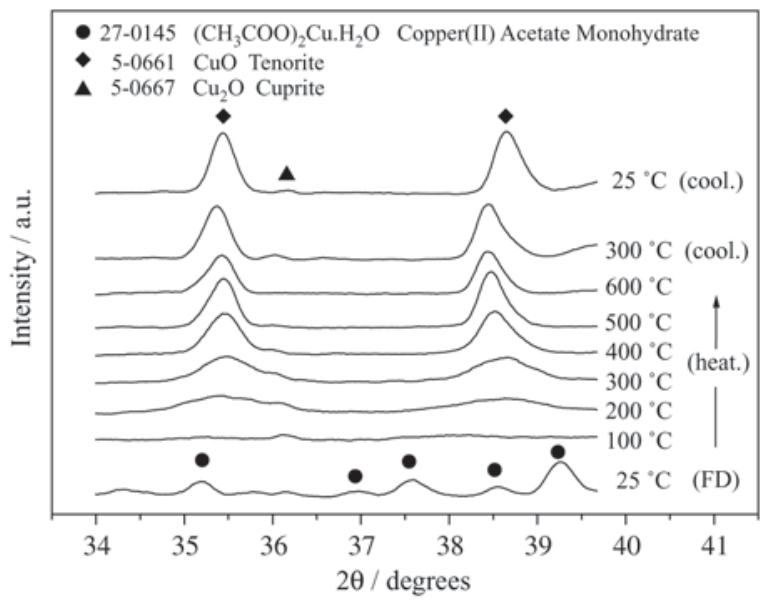

Figure 2. HTXRD spectra for a freeze-dried copper(II) acetate monohydrate.

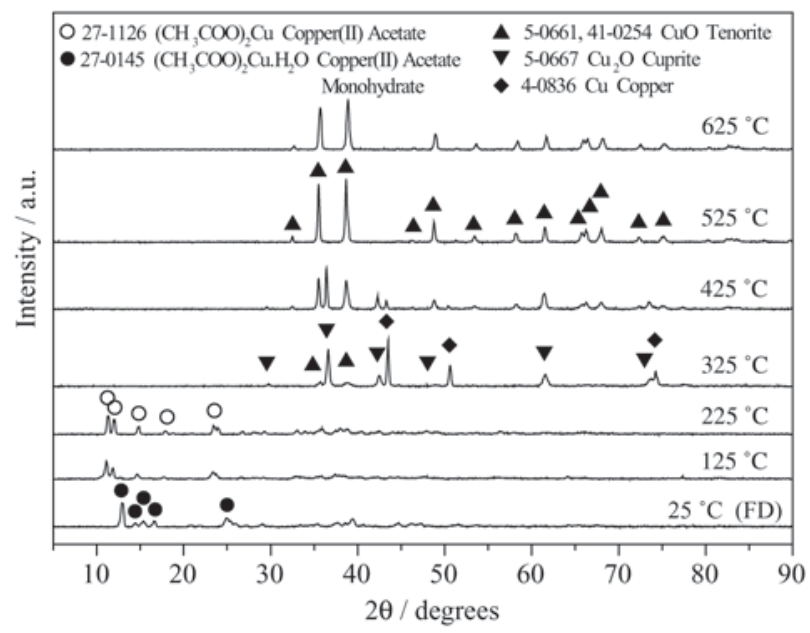

Figure 3. XRD spectra for the copper(II) acetate monohydrate powder: freeze-dried; and calcined at 125 to $625^{\circ} \mathrm{C}$, in air for $1 \mathrm{~h}$.

showed that the $\mathrm{FDCuAcH}_{2} \mathrm{O}$ powder is $\mathrm{CuAcH}_{2} \mathrm{O}$. Comparing the XRD data for $\mathrm{FDCuAcH}_{2} \mathrm{O}$ powder with previous XRD data for the commercial material powder (not presented here) did not indicate any secondary phase. At $100{ }^{\circ} \mathrm{C}$ occurs the dehydration of $\mathrm{FDCuAcH}_{2} \mathrm{O}$ leading to formation of $\mathrm{CuAc}$. At $200{ }^{\circ} \mathrm{C}$ is the beginning of the thermal decomposition process of $\mathrm{CuAc}$ leading probably to formation of $\mathrm{Cu}_{2} \mathrm{O}$ and $\mathrm{CuO}$ phases, simultaneously. In the range $200-400^{\circ} \mathrm{C}$, these amorphous phases crystallise to $\mathrm{CuO}$ in an oxidation process. At 500 and $600{ }^{\circ} \mathrm{C}$, on heating and on cooling from $600{ }^{\circ} \mathrm{C}$ to ambient temperature the present phase is $\mathrm{CuO}$.

The XRD spectra for the $\mathrm{FDCuAcH}_{2} \mathrm{O}$ calcined powders are presented in Fig. 3. At ambient temperature the 
FDCuAcH ${ }_{2} \mathrm{O}$ is identified as $\mathrm{CuAcH}_{2} \mathrm{O}$. After calcination at $125{ }^{\circ} \mathrm{C}$ and $225{ }^{\circ} \mathrm{C}, \mathrm{FDCuAcH}_{2} \mathrm{O}$ dehydrates leading to formation of $\mathrm{AcCu}$. Calcination at $325^{\circ} \mathrm{C}$ gives rise to formation of various coexisting phases that were identified as $\mathrm{Cu}^{0}, \mathrm{Cu}_{2} \mathrm{O}$ and $\mathrm{CuO}$. This indicates that from solid decomposition products of $\mathrm{CuAc}$ in air, $\mathrm{Cu}^{0}, \mathrm{Cu}_{2} \mathrm{O}$ and $\mathrm{CuO}$ can be formed simultaneously, between 225 and $325^{\circ} \mathrm{C}$. XRD
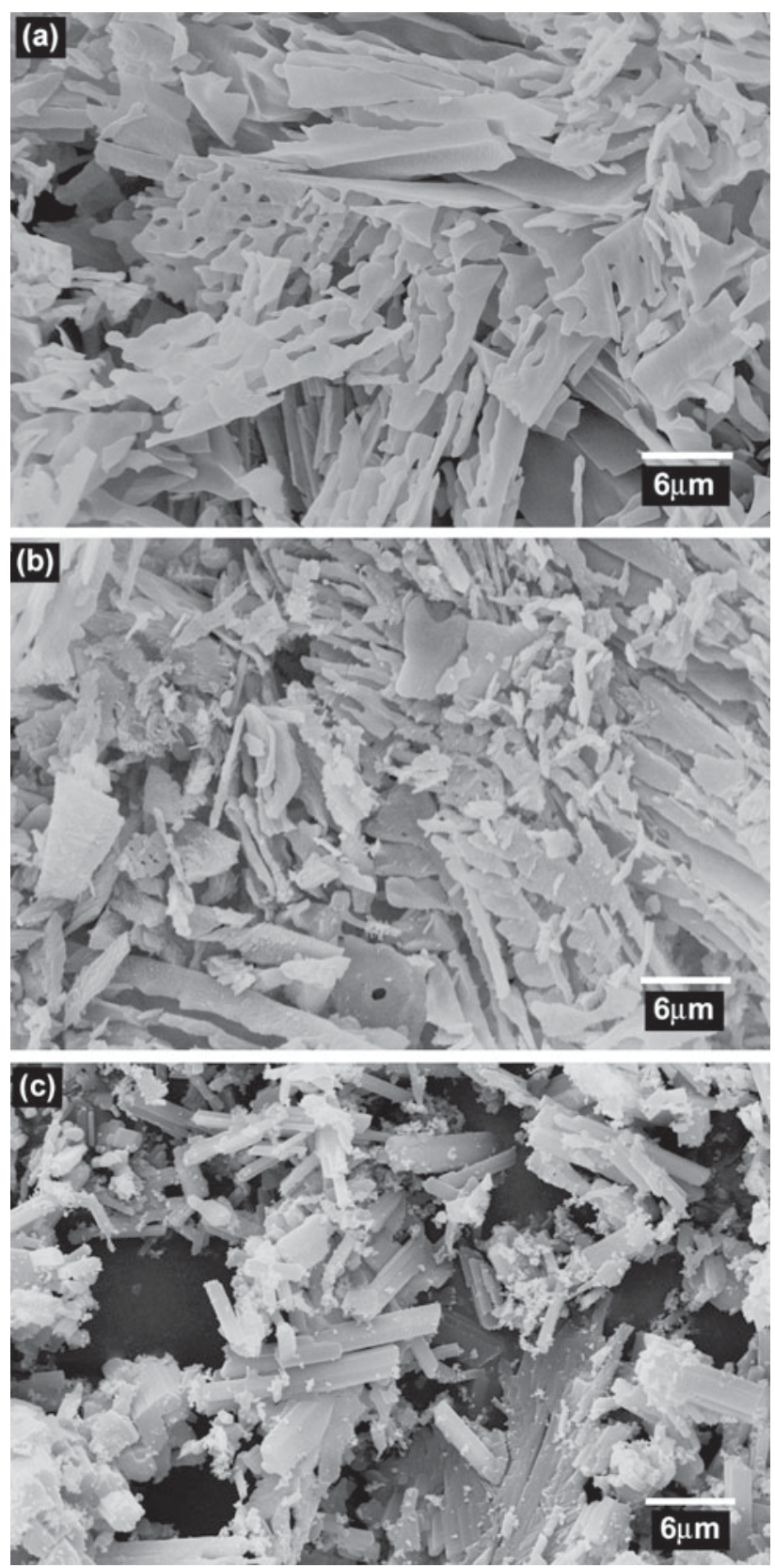

Figure 4. SEM morphological aspects for the copper(II) acetate monohydrate powder: (a) freeze-dried; and calcined at (b) $125^{\circ} \mathrm{C}$; and (c) $225^{\circ} \mathrm{C}$, in air for $1 \mathrm{~h}$. analyses of the calcined powders at 325,425 and $525{ }^{\circ} \mathrm{C}$, indicate that $\mathrm{CuO}$ is formed through oxidation reactions of $\mathrm{Cu}^{\circ}$ and $\mathrm{Cu}_{2} \mathrm{O}$. Above $525{ }^{\circ} \mathrm{C}$ the final product is $\mathrm{CuO}$.

In function of the previously obtained results by DSC-TG, HTXRD, and XRD, the probably reactions giving rise to the solid products of the thermal decomposition of the $\mathrm{FDCuAcH}_{2} \mathrm{O}$ are:

Stage I $\left(25-225^{\circ} \mathrm{C}\right)$ :

$\left(\mathrm{CH}_{3} \mathrm{COO}\right)_{4} \mathrm{Cu}_{2} \cdot 2 \mathrm{H}_{2} \mathrm{O} \rightarrow 2\left(\mathrm{CH}_{3} \mathrm{COO}\right)_{2} \mathrm{Cu}+2 \mathrm{H}_{2} \mathrm{O}$

Stage II $\left(225-525{ }^{\circ} \mathrm{C}\right)$ :

$6 n\left(\mathrm{CH}_{3} \mathrm{COO}\right)_{2} \mathrm{Cu}+1 / 2 \mathrm{O}_{2} \rightarrow \mathrm{Cu}+\mathrm{Cu}_{2} \mathrm{O}+3 n$ Product $_{\text {(gas, volatile) }}$

$\mathrm{Cu}+1 / 2 \mathrm{O}_{2} \rightarrow \mathrm{CuO}$

$2 \mathrm{Cu}+1 / 2 \mathrm{O}_{2} \rightarrow \mathrm{Cu}_{2} \mathrm{O}$

$\mathrm{Cu}_{2} \mathrm{O}+\frac{1}{12} \mathrm{O}_{2} \rightarrow 2 \mathrm{CuO}$

The morphological evolution of the $\mathrm{FDCuAcH}_{2} \mathrm{O}$ powder after calcination was examined by SEM. Figure $4 a, 4 b$ and $4 \mathrm{c}$ ) shows the morphological aspects of the FDCuAcH $\mathrm{H}_{2} \mathrm{O}$ powders at ambient temperature $\left(25^{\circ} \mathrm{C}\right)$, and calcined from 125 to $225{ }^{\circ} \mathrm{C} / 1 \mathrm{~h}$, respectively. The FDCuAcH $\mathrm{O}_{2} \mathrm{O}$ powder, showed in Fig. $4 \mathrm{a}$, has a clear scalelike aspect. The origin of this morphology is probably due to the freeze-drying processing technique used in this work. When the mixture is frozen overlapped solid thin layers are created inside the glass flask. During water sublimation that solid layers are retained giving rise to this interesting and unusual morphology. In a recent work, the characterisation by SEM of a freeze-dried $\mathrm{CuAcH}_{2} \mathrm{O}$ powder, obtained by spray-freeze-drying, showed morphology composed by very thin filaments or chained agglomerates ${ }^{9}$. Studies about the crystalline structure of $\mathrm{CuAcH}_{2} \mathrm{O}$ show that this material tends to form dimmers, $\left(\mathrm{CH}_{3} \mathrm{COO}\right)_{4} \mathrm{Cu}_{2}$, bonded by water molecules, which package in the monoclinic system ${ }^{19-22}$. The

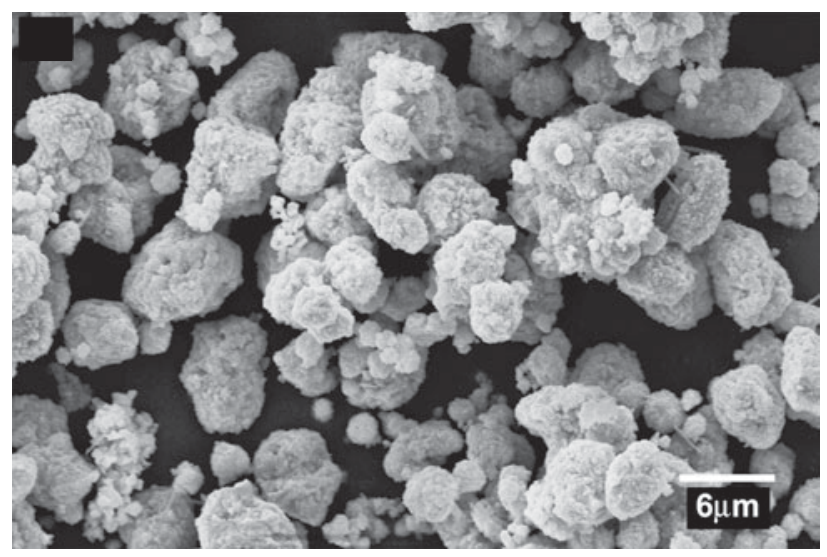

Figure 5. SEM morphological aspects for the copper(II) acetate monohydrate powders, calcined at $425^{\circ} \mathrm{C}$ in air for $1 \mathrm{~h}$. 
morphology of giant $\mathrm{CuAcH}_{2} \mathrm{O}$ single crystals have been reported as been composed by flat faces ${ }^{17,18}$. Analysis of both powder morphology, the $\mathrm{FDCuAcH}_{2} \mathrm{O}$ calcined at 125 and $225^{\circ} \mathrm{C}$, shows that after dehydration the powders form elongated solid tubes, which is characteristic of the open tetragonal structure of $\mathrm{CuAc}$. After calcination at 325, 425 and $525^{\circ} \mathrm{C}, \mathrm{CuAc}$ decomposes to $\mathrm{Cu}^{0}, \mathrm{Cu}_{2} \mathrm{O}$ and $\mathrm{CuO}$, in an oxidation reaction, resulting in hard clusters of spheroid-like $\mathrm{CuO}$ particles (Fig. 5).

\section{Conclusions}

Results obtained in this study show that the freeze-drying synthesis process is reliable for producing copper(II) acetate monohydrate powder $\left(\mathrm{FDAcCuH}_{2} \mathrm{O}\right)$, with an unusual scale-like morphology created in the freezing stage and retained after freeze-drying. Results of the solid decomposition products show that the copper(II) acetate monohydrate powder $\left(\mathrm{FDAcCuH}_{2} \mathrm{O}\right)$ decomposed during heating in two stages: I) $\left(25-225^{\circ} \mathrm{C}\right) \mathrm{FDCuAcH}_{2} \mathrm{O}$ dehydrates giving rise to copper(II) acetate, $(\mathrm{AcCu})$, and II) $\left(225-525^{\circ} \mathrm{C}\right)$ $\mathrm{AcCu}$ decomposes to $\mathrm{CuO}$ through complex oxidation reactions of $\mathrm{Cu}$ and $\mathrm{Cu}_{2} \mathrm{O}$, simultaneously.

The morphological aspect of the products from decomposition of copper(II) acetate monohydrate powder $(\mathrm{FDAcCuH} 2 \mathrm{O})$, between 125 and $225^{\circ} \mathrm{C}$, are elongated solid tubes or filaments of $\mathrm{AcCu}$ and after subsequent calcination above $325^{\circ} \mathrm{C}$ the morphological aspect resulted in hard clusters of spheroid-like $\mathrm{CuO}$ particles.

\section{Acknowledgements}

The authors wish to thank the valuable help of the technical staff of DEMa/UFSCar and also to acknowledge the financial support of CAPES/PICDT and FAPESP.

\section{References}

1. Apelblat, A.; Manzurola, E. J. Chem. Thermodynamics, v. 31, p. 1347-1357, 1999.

2. Schnettler, F.J.; Monforte, F.R.; Rhodes, W.H. Science of Ceramics, v. 4, p. 79-90. Edited by G.H. Stewart. The British Ceramic Society, Stoke-on-Trent, England, 1968. 3. Johnson Jr., D.W.; Gallagher, P.K.; Schnettler, F.J.; Vogel,
E.M. Ceram. Bull., v. 56, n. 9, p. 785-788, 1974.

4. Thomson Jr., J.; Ceram. Bull., v. 53, n. 5, p. 421-424 and 433, 1974.

5. Akbas, M.A.; Lee, W.E. J. Eur. Ceram. Soc, v. 15, p. 5763, 1995.

6. Tachiwaki, T; Suzuki, M.; Okajima, H.; Koizumi, S.; Ito, T.; Hiraki, A. Appl. Surf. Sci., v. 70/71, p. 751-754, 1993.

7. Song, K-H.; Liu, H-K.; Dou, S.-X.; Sorelli, C.C. J. Am. Ceram. Soc., v. 73, n. 6, p. 1771-1773, 1990.

8. Dierickx, D.; van der Biest, O. Eur. J. Solid State Inorg. Chem., v. 32, p. 711-718, 1995.

9. Alconchel, S.A.; Ulla, M.A.; Lombardo,E.A. Mater. Sci. Eng., v. B38, p. 205-215, 1996.

10. Bellini, J.V. Ph.D. Thesis. Universidade Federal de São Carlos (UFSCar), Departamento de Engenharia de Materiais (DEMa), p. 142, São Carlos/SP, Brasil, 2001 (In portuguese).

11. Bellini, J.V.; Morelli, M.R.; Kiminami, R.H.G.A. J. Mater. Sci., v. 13, p. 479-483, 2001.

12. Hill, J.A.; Murphy, C.B.; Schacher, G.P. Anal. Chim. Acta, v. 24, p. 496-497, 1961.

13. Edwards, D.A.; Hayward, R.N. Can. J. Chem., v. 46, p. 3443-3446, 1968.

14. Patil, K.C.; Chandrashekhar, G.V.; George, M.V.; Rao, C.N.R. Can. J. Chem., v. 46, p. 257-265, 1968.

15. Judd, M.D.; Plunkett, B.A.; Pope, M.I. J. Thermal Anal., v. 6, p. 555-563, 1974.

16. Maslowska, J.; Baranowska, A. J. Thermal Anal., v. 29, p. 309-315, 1984.

17. Ball, M.C.; Portwood, L. J. Thermal Anal., v. 41, p. 347-356, 1994.

18. Mansour, S.A.A. J. Thermal Anal., v. 46, p. 263-274, 1996.

19. van Niekerk, J.N.; Schoening, F.R.L. Acta Cryst., v. 6, p. 227-232, 1953.

20. de Meester, P.; Fletcher, S.R.; Skapski, A.C. J. Chem. Soc. Dalton Trans., p. 2575-2578, 1973.

21. Bell, S.J.; Jennings, K.L.; Danielson, E.D.; Solomon, E.I.; Musselman, R.L. J. Crystal Growth, v. 154, p. 108112, 1995.

22. Quilès, F.; Burneau, A. Vibrational Spectroscopy, v. 16, p. 105-117, 1998. 